\title{
ANALISIS KEGIATAN EKONOMI ATAS HAK CIPTA DALAM \\ EKONOMI ISLAM \\ FASIHA
}

fasihakamal@gmail.com

\begin{abstract}
The existence of sharia provisions and protection of the law on copyright provide adequate legal protection, of course so that the ability of intellectual rights, creativity, or community expertise can grow in line with a climate of fair business competition. Copyright can be justified by Islamic economics in terms of distributive justice. Considerations of fairness are strong reasons for supporting copyright. It is fair that inventors get rewarded for providing a service to society. On the other hand, it would be unfair for other people to become "stowaways" at the expense of others who have attempted to carry out new research and discoveries. Incentives also need to be given to inventors because without them it would be impossible to develop art, science and technology. Because the freedom that an inventor has is an invaluable asset for the progress of society. Therefore, the protection of what he finds deserves to be given by society.
\end{abstract}

Key words: copyright, Islamic economy

\begin{abstract}
ABSTRAK
Adanya ketentuan syariah dan perlindungan Undang-undang tentang hak cipta memberikan perlindungan hukum yang memadai, tentunya supaya kemampuan hak intelektual, kreativitas, atau keahlian masyarakat dapat tumbuh sejalan dengan iklim persaingan usaha yang sehat. Hak cipta dapat dibenarkan oleh Ekonomi Islam dari segi keadilan distributif. Pertimbangan mengenai keadilan merupakan alasan yang kuat untuk mendukung hak cipta. Adil bahwa penemu mendapatkan reward karena memberikan layanan bagi masyarakat. Sebaliknya, akan menjadi tidak adil jika orang lain menjadi "penumpang gelap" atas biaya orang lain yang telah berusaha melakukan penelitian dan penemuan baru. Insentif juga perlu diberikan kepada penemu karena tanpa dia tidak mungkin terjadi perkembangan seni, ilmu dan teknologi. Karena kebebasan yang dimiliki seorang penemu merupakan modal yang yang tak ternilai bagi kemajuan masyarakat. Oleh karena itu, perlindungan atas apa yang ia temukan pantas diberikan oleh masyarakat.
\end{abstract}


Kata kunci: hak cipta, ekonomi Islam

\section{PENDAHULUAN}

Rasa ingin tahu menyebabkan manusia berusaha untuk menemukan hal-hal yang baru, proses penemuan tersebut dilakukannya di dalam suatu pola tertentu dengan harapan dapat terpenuhinya kebutuhan-kebutuhan dasarnya baik material maupun spritual. Berdasarkan pola perilaku tertentu yang berlaku dalam masyarakat, manusia menghasilkan kebudayaan sebagai hasil karya, rasa dan cipta untuk memenuhi kebutuhan-kebutuhannya itu. ${ }^{1}$ Rasa dan cipta masyarakat menghasilkan norma-norma dan ilmu pengetahuan, sedangkan karya masyarakat menghasilkan teknologi yang diperlukan manusia untuk menguasai alam sekitarnya agar kekuatan serta hasilnya dapat diabadikan untuk keperluan masyarakat. Semua karya, rasa, dan cipta ini dikuasai oleh orang-orang yang menentukan kegunaannya agar sesuai dengan kepentingan sebagian besar atau seluruh warga di dalam masyarakat.

Perkembangan teknologi menghasilkan barang-barang kebutuhan primer dan sekunder. Dengan meningkatnya jenis maupun jumlah sirkulasi barang, menyebabkan permasalahan Hak Cipta di dalam masyarakat. Hal ini mengingat semakin banyaknya praktek-praktek persaingan usaha yang tidak sehat berupa pemalsuan, maupun pelanggaran hak cipta. Kesemuanya itu dirasakan sangat merugikan dan mempunyai sifat melawan hukum. Permasalahan ini terus saja banyak terjadi, hingga saat ini belum juga ditemukan bagaimana cara menanggulangi terhadap banyaknya kasus-kasus pelanggaran hak cipta. Sedangkan hak cipta ini berperan sebagai motivasi untuk kegairahan dan kesinambungan mencipta pada khususnya dan memberikan iklim kondusif demi perkembangan kebudayaan manusia pada umumnya. 


\section{Ketentuan Umum Hak Cipta}

\section{Definisi Hak Cipta}

Hak cipta merupakan istilah populer di dalam masyarakat. Walaupun demikian pemahaman tentang ruang lingkup pengertiannya tidaklah sama pada setiap orang karena berbeda tingkat pemahaman tentang istilah itu. Akibatnya di dalam masyarakat sering terjadi kesalahpahaman dalam memberi arti sehingga sehingga menimbulkan kerancuan dalam penggunaan bahasa yang baik dan benar. Dalam masyarakat istilah hak cipta ini sering dikacaukan dengan hak-hak atas kekayaan intelektual lainnya meliputi keseluruhan ciptaan manusia. Di samping ciptaan manusia, terdapat ciptaan Tuhan yang tidak dimaksukkan sebagai hak cipta.

Perkataan hak cipta itu sendiri terdiri dari 2 kata yaitu "hak" dan "cipta". Kata hak yang sering dikaitkan dengan kewajiban adalah milik kepunyaan, kekuasaan untuk berbuat sesuatu (karena telah ditentukan oleh undang-undang, aturan dan sebagainya). ${ }^{2}$ Sedangkan yang dimaksud dengan kata cipta adalah kesanggupan pikiran untuk mengadakan sesuatu yang baru: angan-angan kreatif. ${ }^{3}$ Oleh karena itu, hak cipta berkaitan erat dengan intelektualitas manusia itu sendiri berupa hasil kerja otak.

Menurut ketentuan Pasal 1 ayat 1 Undang-Undang Hak Cipta No. 19 Tahun 2002: "Hak Cipta adalah hak eksklusif bagi Pencipta atau penerima hak untuk mengumumkan atau memperbanyak Ciptaannya atau memberikan izin untuk itu dengan tidak mengurangi pembatasan-pembatasan menurut peraturan perundangundangan yang berlaku". Dari pengertian ini terlihat bahwa Hak Cipta ini diberikan kepada yang berhak saja, yaitu pencipta, tidak kepada pihak lain untuk boleh memanfaatkannya tanpa izin pemegangnya. ${ }^{4}$ Oleh karena itu, pencipta memiliki hak monopoli terhadap ciptaannya yang dilindungi. Namun kekuasaan monopoli atau kekuasaan istimewa demikian bukan tanpa batas (mutlak). Batasannya ditentukan sendiri di dalam Undang-Undang Hak Cipta.

2 Pusat Pembinaan dan Pengembangan Bahasa, Kamus Besar Bahasa Indonesia, (Jakarta: Balai Pustaka, 1996), hal. 292.

${ }^{3}$ Ibid, hal.169 Hal. 41

${ }^{4}$ Hadi Setia Tunggal, Undang-Undang Hak Cipta (UU No. 19 Tahun 2002), (Jakarta: Harvindo, 2003), 
Suatu ciptaan sebenarnya tidak wajib didaftarkan karena pendaftaran hanya merupakan alat pembuktian saja bila ada pihak lain yang ingin mengakui hasil ciptaannya di kemudian hari. Menurut teorinya, hak cipta dapat dibagi atas:

\section{a. Hak moral (moral rights)}

Hak moral adalah hak dari seorang pencipta yang tidak dapat diambil sedemikian rupa tanpa izin dari pemegang hak cipta. Artinya hak untuk pemakaian, untuk mengubah isi/nama/judul dari ciptaannya, untuk mengumumkan ciptaannya, melekat pada penciptaannnya. Orang lain dilarang untuk mengumumkan, memakai atau mengubah hasil ciptaan seseorang. ${ }^{5}$ Hak ini melindungi kepentingan pribadi atau reputasi pencipta atau penemu. Moral right ini tidak dapat lepas atau dirampas dari penciptanya. Bila dikaitkan dengan universal declaration of human right, moral right jelas dipegang oleh penciptanya dan tidak bisa dirampas pihak lain karena bersifat pribadi dan kekal. Sifat pribadi menunjukkan ciri khas yang berkenaan dengan nama baik, kemampuan, dan integritas yang hanya dimiliki oleh pencipta atau penemu. Kekal artinya melekat pada pencipta atau penemu selama hidup bahkan setelah meninggal dunia. ${ }^{6}$

\section{b. Hak ekonomi (economic rights)}

Hak ekonomi adalah hak untuk memperoleh keuntungan ekonomi atas hak cipta. Dikatakan hak ekonomi karena hak cipta adalah benda yang dapat dinilai dengan uang. Hak ekonomi tersebut berupa keuntungan sejumlah uang yang diperoleh karena penggunaan oleh pihak lain berdasarkan lisensi. Hak ekonomi itu diperhitungkan karena hak cipta dapat digunakan atau dimanfaatkan oleh pihak lain dalam perindustrian atau perdagangan yang mendatangkan keuntungan. Pada hak cipta, jenis hak ekonomi lebih banyak jika dibandingkan dengan paten dan merek. Jenis hak ekonomi pada hak cipta adalah: 1) Hak perbanyakan (penggandaan), 2)

\footnotetext{
${ }^{5}$ Lihat Pasal 24 ayat $1 \& 2$ Undang-Undang Hak Cipta No. 19 Tahun 2002

6 Abdul Kadir Muhammad, Kajian Hukum Ekonomi Hak Kekayaan Intelektual, (Bandung: PT. Citra Bakti, 2001) hal.22
} 
Hak adaptasi (penyesuaian), 3) Hak pengumuman (penyiaran), 4) Hak pertunjukkan (penampilan). ${ }^{7}$

Dua macam hak cipta yang dapat diserahkan kepada pihak lain yang disebut dengan lisensi dan assignment. Lisensi adalah suatu pemberian hak kepada orang lain oleh si pemegang hak untuk dapat melaksanakan haknya tadi. Sedangkan assignment adalah penyerahan untuk keseluruhannya, sehingga dapat mencetak, menjual, memfilmkan, dan sebagainya. Penyerahan ini bisa kepada pemerintah atau kepada seseorang. Tetapi moral rightnya tetap dimiliki pencipta. ${ }^{8}$

\section{Pencipta, Ciptaan, dan Pemegang Hak Cipta}

Menurut ketentuan Pasal 1 ayat 2 Undang-Undang Hak Cipta No. 19 Tahun 2002: "Pencipta adalah seorang atau beberapa orang secara bersama-sama yang atas inspirasinya melahirkan suatu Ciptaan berdasarkan kemampuan pikiran, imajinasi, kecekatan, keterampilan, atau keahlian yang dituangkan ke dalam bentuk yang khas dan bersifat pribadi”. Dari definisi tersebut, pada dasarnya yang digolongkan sebagai pencipta adalah seseorang yang melahirkan suatu ciptaan untuk pertama kali sehingga ia adalah orang pertama yang mempunyai hak-hak sebagai pencipta.

Menurut ketentuan Pasal 1 ayat 3 Undang-Undang Hak Cipta No. 19 Tahun 2002: "Ciptaan adalah hasil setiap karya Pencipta yang menunjukkan keasliannya dalam lapangan ilmu pengetahuan, seni, atau sastra". Menunjukkan keaslian artinya bukan tiruan atau jiplakan dari ciptaan orang lain. Ciptaan ini bersifat pribadi artinya berasal dari kemampuan intelektual yang menyatu dengan diri pencipta. Perlu ada keahlian pencipta untuk melakukan karya cipta yang dilindungi oleh hak cipta. Ciptaan yang lahir harus mempunyai bentuk yang khas dan menunjukkan keaslian sebagai ciptaan seseorang atas dasar kemampuan dan kreativitasnya yang bersifat pribadi pencipta. $^{9}$

Menurut ketentuan Pasal 1 ayat 4 Undang-Undang Hak Cipta No. 19 Tahun 2002: "Pemegang Hak Cipta adalah Pencipta sebagai Pemilik Hak Cipta, atau pihak yang menerima hak tersebut dari Pencipta, atau pihak lain yang menerima lebih lanjut

\footnotetext{
${ }^{7}$ Abdul Kadir Muhammad, Kajian Hukum Ekonomi....., hal.19

${ }^{8}$ Richard Burton Simatupang, Aspek Hukum dalam Bisnis, (Jakarta: PT. Rineka Cipta, 2003), hal. 69

${ }^{9}$ Eddy Damian, Hukum Hak Cipta, (Bandung: Penerbit Alumni, 2002), hal.131
} 
hak dari pihak yang menerima hak tersebut". Dengan demikian, pencipta otomatis menjadi pemegang hak cipta, yang merupakan pemilik hak cipta, sedangkan yang menjadi pemegang hak cipta tidak harus penciptanya, tetapi bisa pihak lain yang menerima hak tersebut dari pencipta atau pihak lain yang menerima lebih lanjut hak tersebut dari pencipta atau pemegang hak cipta yang bersangkutan. Keadaan beralihnya hak cipta dari pencipta kepada orang lain yang menerima hak tersebut dilakukan pencipta melalui proses penyerahan (assignment) atau pemberian lisensi (licensing) kepada seseorang.

\section{Ciptaan yang dilindungi}

Menurut ketentuan Pasal 12 ayat 1 Undang-Undang Hak Cipta No. 19 Tahun 2002: "Ciptaan yang dilindungi adalah Ciptaan dalam bidang ilmu pengetahuan, seni, dan sastra". Hal ini tentunya berbeda dengan paten yang diberikan di bidang teknologi. Teknologi sendiri pengertiannya lebih sempit daripada ilmu pengetahuan, yaitu terbatas pada ilmu pengetahuan yang dapat diterapkan dalam proses industri, jadi teknologi lebih berupa ilmu pengetahuan terapan. ${ }^{10}$ Dalam rumusan pasal tersebut di atas dapat dilihat bahwa perlindungan yang diberikan oleh undang-undang tidak hanya pada karya-karya atau ciptaan-ciptaan yang asli saja, akan tetapi juga terhadap karyakarya atau ciptaan-ciptaan yang bersifat turunan (derivatif) atau pengalihwujudan atau juga pengolahan.

\section{Pengumuman dan Perbanyakan}

Menurut ketentuan Pasal 1 ayat 5 \& 6 Undang-Undang Hak Cipta No. 19 Tahun 2002: "Pengumuman adalah pembacaan, penyiaran, pameran, penjualan, pengedaran, atau penyebaran suatu Ciptaan dengan menggunakan alat apa pun, termasuk media internet, atau melakukan dengan cara apa pun sehingga suatu Ciptaan dapat dibaca, didengar, atau dilihat orang lain. Sedangkan perbanyakan adalah penambahan jumlah sesuatu Ciptaan, baik secara keseluruhan maupun bagian yang sangat substansial dengan menggunakan bahan-bahan yang sama ataupun tidak sama, termasuk mengalihwujudkan secara permanen atau temporer". Pengertian

\footnotetext{
${ }^{10}$ Eddy Damian, Hukum Hak Cipta..., hal. 44
} 
"mengumumkan atau memperbanyak" termasuk juga kegiatan menerjemahkan, mengadaptasi, mengaransemen, mengalihwujudkan, menjual, menyewakan, meminjamkan, mengimpor, memamerkan, mempertunjukkan kepada publik, menyiarkan, merekam, dan mengkomunikasikan ciptaan kepada publik melalui sarana apapun.

\section{Peralihan Hak Cipta}

Hak cipta merupakan kekayaan intelektual yang dapat dieksploitasi hak-hak ekonominya seperti kekayaan-kekayaan lainnya, timbul hak untuk mengalihkan kepemilikan atas hak cipta, seperti misalnya dengan cara penyerahan (assignment) hak cipta tersebut. Pemegang hak cipta dapat juga memberikan lisensi untuk penggunaan karya hak cipta. Bila pemegang hak cipta menyerahkan hak ciptanya, ini berarti terjadi pengalihan keseluruhan hak-hak ekonominya yang dapat dieksploitasi dari suatu ciptaan yang dialihkan kepada penerima/pemegang hak cipta dalam jangka waktu yang telah disetujui bersama. Lain halnya jika pengalihan hak cipta dilakukan dengan lisensi. Dengan pengalihan hak cipta secara lisensi, pencipta masih memiliki hak-hak ekonomi tertentu dari ciptaan yang dialihkan kepada pemegang hak cipta.

Cara pengalihan atau beralihnya hak cipta diatur dalam ketentuan Pasal 3 ayat 1 \& 2 Undang-Undang Hak Cipta No. 19 Tahun 2002: "Hak Cipta dianggap sebagai benda bergerak dan dapat beralih atau dialihkan, baik seluruhnya maupun sebagian karena: a) Pewarisan; b) Hibah; c) Wasiat; d) Perjanjian tertulis; atau e) Sebabsebab lain yang dibenarkan oleh peraturan perundang-undangan”. Pengalihan hak cipta didasari oleh motif ekonomi, yaitu keinginan untuk memperoleh manfaat ekonomi atau keuntungan secara komersial. Pencipta mengalihkan hak cipta dengan tujuan memperoleh royalti, sedangkan penerima selaku pemegang hak cipta bertujuan memperoleh keuntungan ekonomi dari penjualan ciptaan yang dihasilkan dari hak cipta tersebut.

\section{Jangka Waktu Perlindungan Hak Cipta}

Perlindungan hukum terhadap Hak Cipta pada dasarnya dimaksud sebagai upaya untuk mewujudkan iklim yang sehat bagi tumbuh dan kembangnya gairah dalam 
mencipta di bidang ilmu pengetahuan, seni dan sastra. Untuk mencapai rasa keadilan, jangka waktu perlindungan Hak Cipta itu dikaitkan dengan hak masyarakat atau kepentingan umum terhadap suatu ciptaan. Apabila suatu ciptaan sudah habis jangka waktu perlindungannya sebagaimana yang telah ditetapkan oleh undang-undang hak cipta, maka ia menjadi milik masyarakat. Setiap orang bebas untuk memperbanyak, mengumumkan dan menyewakan ciptaan yang sudah habis jangka waktu perlindungannya itu, tanpa memerlukan lagi mekanisme pembayaran royalti dan pembuatan perjanjian lisensi.

Menurut ketentuan Pasal 29 ayat 2 Undang-Undang Hak Cipta No. 19 Tahun 2002: "Karya cipta atau ciptaan yang berlaku selama hidup pencipta dan terus berlangsung hingga 50 tahun setelah pencipta meninggal dunia, dan apabila karya cipta itu dimiliki oleh 2 orang atau lebih, maka hak cipta berlaku selama hidup pencipta yang meninggal dunia paling akhir dan berlangsung selama 50 tahun sesudah ia meninggal".

\section{HAK CIPTA MENURUT EKONOMI ISLAM}

Pada dasarnya kepemilikan individu atas sumberdaya ekonomi (sumberdaya) merupakan salah satu fitrah manusia karena ajaran Islam mengakui sebagai suatu yang harus dihormati dan dijaga. Kepemilikan individu merupakan persyaratan yang mendasar bagi tercapainya kesejahteraan masyarakat, sebab ia akan menciptakan motivasi dan memberikan ruang bagi seorang individu untuk memanfaatkan sumberdaya secara optimal. Seorang individu diberikan kebebasan tinggi untuk memiliki dan memanfaatkan sumberdaya bagi kepentingan sepanjang: a) cara perolehan dan penggunaannya tidak bertentangan dengan syariah Islam, dan b) tidak menimbulkan kerugian, baik bagi diri sendiri maupun orang lain. ${ }^{11}$

\section{Hak cipta sebagai hak kebendaan}

Dalam kehidupan sehari-hari sering didengar perkataan "benda" yang merujuk pada pengertian yang sempit, yakni barang-barang yang hanya dapat dilihat saja. Apabila perkataan benda ini dikaitkan dengan kekayaan seseorang, maka akan

11 Pusat Pengkajian dan Pengembangan Ekonomi Islam (P3EI), Ekonomi Islam, (Jakarta: PT. Raja Grafindo Persada, 2008), hal.76 
mengandung arti bukan saja barang-barang yang dapat dilihat akan tetapi juga barangbarang yang tidak terlihat. Sedangkan pengertian yang paling luas dari perkataan benda ialah segala sesuatu yang dapat dihaki oleh orang. ${ }^{12}$ Hal ini mengandung pengertian bahwa benda sebagai objek dalam pengertian hukum, sedangkan lawannya adalah subjek hukum yaitu orang dan badan hukum.

Terminologi "benda" menurut Undang-undang dapat dilihat dalam pasal 499 KUH Perdata, yang menyebutkan: menurut Paham undang-undang yang dinamakan kebendaan ialah, tiap-tiap barang dan tiap-tiap hak, yang dapat dikuasi oleh hak miik. ${ }^{13}$ Ketentuan ini mendefiniskan benda menjadi dua kelompok, yakni barang untuk bendabenda yang dapat dilihat dan diraba (berwujud), dan hak untuk benda-benda yang tidak dapat dilihat dan tidak dapat diraba (tidak berwujud). Pembagian benda berdasarkan klasifikasi sebagai berikut:

a. Benda yang dapat diganti seperti uang dan yang tidak dapat diganti seperti kuda

b. Benda yang dapat diperdagangkan dan tidak dapat diperdagangkan

c. Benda yang dapat dibagi seperti beras dan tidak dapat dibagi seperti kuda

d. Benda yang bergerak dan yang tidak dapat bergerak. ${ }^{14}$

Dalam kaitannya dengan hak cipta, maka hak cipta termasuk ke dalam lingkup benda bergerak, sebagaimana dalam Pasal 3 ayat 1 Undang-Undang Hak Cipta No. 19 Tahun 2002. Dalam bahasa Belanda hak kebendaan ini disebut zakelijk recht. Sofwan memberikan rumusan tentang hak kebendaan yakni: "hak mutlak atas suatu benda dimana hak itu memberikan kekuasaan langsung atas suatu benda dan dapat dipertahankan terhadap siapapun juga". ${ }^{15}$

Hak kebendaan dibagi menjadi dua: hak kebendaan yang sempurna dan hak kebendaan yang terbatas. Hak kebendaan yang sempurna adalah hak kebendaan yang memberikan kenikmatan yang sempurna (penuh) bagi sipemilik. Oleh karena itu dinamakan dengan hak kemilikan. Sedangkan hak kebendaan terbatas adalah hak yang

\footnotetext{
${ }^{12}$ Subekti, Pokok-Pokok Perdata, (Jakarta: PT. Intermasa, 1980), hal.60

${ }^{13}$ R. Subekti dan R. Tjitrosudibio, Kitab Undang-undang Hukum Perdata, (Jakarta: Pradnya Paramita, 1982), hal. 155

${ }^{14}$ Subekti, Pokok-pokok...., hal.61

${ }^{15}$ Sri Soedawi dan Masjchoen Sofwan, Hukum Perdata: Hukum Benda, (Yogyakarta: Liberty, 1981), hal.19
} 
memberikan kenikmatan yang tidak penuh atas suatu benda. Jika dibandingkan dengan hak milik. Artinya hak kebendaan terbatas itu tidak penuh atau kurang sempurna jika dibandingkan dengan hak milik. ${ }^{16}$ Jika dikaitkan dengan hak cipta maka dapatlah dikatakan hak cipta itu sebagai hak kebendaan. Pandangan ini dapat disimpulkan dari Pasal 1 ayat 1 Undang-Undang Hak Cipta Tahun 2002.

Para ulama kontemporer seperti Wahbah zuhaili berpendapat bahwa hak milik termasuk harta, oleh karenanya hak cipta dilindungi oleh syariat. Pendapat ini merujuk pada definisi harta menurut jumhur ulama. Konsekwensi hukum atas pengakuan hak milik sebagai harta adalah:

a. Hak cipta adalah termasuk hak milik pribadi, dengan demikian maka syariat melindungi hak cipta dari segala tindakan yang melanggarnya.

b. Pemilik hak cipta diperbolehkan untuk mentasarufkan haknya, seperti menjualnya atau memberikan hak cetak kepada penerbit tertentu.

c. Hak cipta dimiliki oleh penciptanya atau penemunya, dan dapat diwariskan kepada ahli warisnya jika sang pemilik wafat.

d. Perbuatan mencetak, memperbanyak, menterjemah karya tulis tanpa seizin pemiliknya adalah perbuatan yang dilarang oleh syariat.

Pendapat ini juga diamini oleh fatwa MUI no1/Munas/MUI/15/2005 bahwa hak kekayaan intelektual dalam Islam termasuk hak kekayaan yang mendapat perlindungan hukum sebagaimana harta.

\section{Hak Cipta sebagai kepemilikan}

Kepemilikan sebenarnya berasal dari bahasa Arab dari akar kata malaka yang artinya memiliki. Dalam bahasa Arab, milk berarti kepenguasaan orang terhadap sesuatu (barang atau harta), dan membuat seseorang memiliki kewenangan terhadapnya, dan ia berhak melakukan tasharruf apa saja selama tidak ada larangan yang menghalanginya untuk itu ${ }^{17}$. Dimensi kepenguasaan ini direfleksikan dalam bentuk bahwa orang yang memiliki sesuatu barang berarti mempunyai kekuasaan terhadap

\footnotetext{
16 Mariam Darus Badrulzaman, Mencari Sistem Hukum Benda Nasional, (Bandung: BPHN-Alumni, 1983), hal.43

${ }^{17}$ Wahbah Zuhaili, al-Fiqh al-Islami wa Adilllatuhu, juz 4, (Bairut: Dar al-Fikr al-Mu`ashir, 1998), hal. $402-403$
} 
barang tersebut sehingga ia dapat mempergunakannya menurut kehendaknya, baik itu secara individual maupun kelembagaan, dan tidak ada orang lain yang dapat menghalang-halanginya dari memanfaatkan barang yang dimilikinya itu.

Dalam kaitannya dengan hak cipta, maka hak cipta termasuk dalam kepemilikan seseorang yang memiliki wewenang terhadapnya. Kewenangan ini ada dalam ketentuan Pasal 1 ayat 5 \& 6 Undang-Undang Hak Cipta No. 19 Tahun 2002: "Pengumuman adalah pembacaan, penyiaran, pameran, penjualan, pengedaran, atau penyebaran suatu Ciptaan dengan menggunakan alat apa pun, termasuk media internet, atau melakukan dengan cara apa pun sehingga suatu Ciptaan dapat dibaca, didengar, atau dilihat orang lain. Sedangkan perbanyakan adalah penambahan jumlah sesuatu Ciptaan, baik secara keseluruhan maupun bagian yang sangat substansial dengan menggunakan bahan-bahan yang sama ataupun tidak sama, termasuk mengalihwujudkan secara permanen atau temporer".

Ekonomi Islam adalah bagian dari sistem islam yang bersifat umum yang berlandaskan pada prinsip pertengahan dan keseimbangan yang adil (tawadzun). Islam, menyeimbangkan kehidupan antara dunia dan akhirat, antara individu dan masyarakat. Dalam memandang hak milik ini islam sangat moderat. Dan sangat bertolak belakang dengan sistem kapitalis yang menyewakan hak milik pribadi, sistem sosialis yang tidak mengakui hak milik individu. Oleh karena itu, Islam sangat mengakui adanya kepemilkan pribadi disamping kepemilikan umum. Dan menjadikan hak milik pribadi sebagai dasar bangunan ekonomi. Dan Itu pun akan terwujud apabila ia berjalan sesuai dengan aturan Allah SWT. Berdasarkan konsep kepemilikan dalam Ekonomi Islam, maka kepemilikan individu atas hak cipta diatur sebagai berikut:

a. Sifat kepemilikan, Allah adalah pemilik mutlak sementara manusia memiliki hak kepemilikan terbatas

b. Hak pemanfaatan, pemanfaatan oleh manusia mengikuti ketentuan Allah

c. Prioritas kepemilikan, hak milik individu dan kolektif diatur oleh agama

d. Peran individu, terdapat kewajiban individu secara proposional

e. Distribusi kepemilikan, sebagian diatur oleh pasar, pemerintah dan langsung oleh Al-Qur'an 
f. Tanggungjawab pemanfaatan, pertanggungjawaban kepada diri, publik dan Allah di dunia dan akhirat. ${ }^{18}$

\section{Dalil-dalil pengakuan dan perlindungan hak cipta}

a. Firman Allah SWT tentang larangan memakan harta orang lain secara batil dan larangan merugikan harta maupun hak orang lain, antara lain :

"Hai orang beriman! Janganlah kamu saling memakan harta sesamamu dengan jalan yang batil, kecuali dengan jalan perniagaan yang berlaku dengan suka samasuka di antara kamu. Dan janglah kamu membunuh dirimu; sesungguhnya Allah adalah Maha Penyayang kepadamu” (QS. Al-Nisa':29). "Dan janganlah kamu merugikan manusia pada hak-haknya dan janganlah kamu merajalela di muka bumi dengan membuat kerusakan”(QS. al Syu ra:183). “..kamu tidak menganiaya dan tidak (pula) dianiaya" (QS. al-Baqarah:279)

b. Hadis-hadis Nabi berkenaan dengan harta kekayaan, antara lain:

"Barang siapa meninggalkan harta (kekayaan), maka (harta itu) untuk ahli warisnya, dan barang siapa meninggalkan keluarga (miskin), serahkan kepadaku" (H.R. Bukhari). "Sesungguhnya darah (jiwa) dan hartamu adalah haram (mulia, dilindungi)...”(H.R. al-Tirmizi). "Rasulullah saw. Menyampaikan khutbah kepada kami; sabdanya: 'Ketahuilah: tidak halal bagi seseorang sedikit pun dari harta saudaranya kecuali dengan kerelaan hatinya..." (H.R. Ahmad).

c. Hadis-hadis tentang larang berbuat zalim, antara lain :

"Hai para hamba-Ku! Sungguh Aku telah haramkan kezaliman atas diri-Ku dan Aku jadikan kezaliman itu sebagai hal yang diharamkan diantaramu; maka, janganlah kamu saling menzalimi...”(H.R Muslim)."Muslim adalah saudara muslim (yang lain); ia tidak boleh menzalimi dan menghinanya.."(H.R. Bukhari). Hadis Nabi riwayat Ibnu Majah dari 'Ubadah bin Shamit, riwayat Ahmad dari Ibnu 'Abbas, dan Malik dari Yahya : "Tidak boleh membahayakan (merugikan) diri sendiri dan tidak boleh pula membahayakan (kerugikan) orang lain."

d. Qawa'id fiqh :

\footnotetext{
${ }^{18}$ Pusat Pengkajian dan Pengembangan Ekonomi Islam (P3EI), Ekonomi Islam......, hal. 77
} 
"Bahaya (kerugian) harus dihilangkan." "Menghindarkan mafsadat didahulukan atas mendatangkan maslahat." "Segala sesuatu yang lahir (timbul) dari sesuatu yang haram adalah haram." "Tidak boleh melakukan perbuatan hukum atas (menggunakan) hak milik orang lain tanpa seizinnya."

\section{PENDAPAT ULAMA TENTANG HAK CIPTA}

Mengingat tidak ada nash yang secara eksplisit yang membahas hak cipta, maka menurut Wahbah zuhaili pembahasan tentang hak cipta menggunakan dalil maslahah mursalah yaitu bahwa setiap sesuatu atau tindakan yang sesuai dengan tujuan syariat Islam, dan mempunyai nilai mendatangkan kebaikan dan menghilangkan kerusakan, namun tidak mempunyai dalil eksplisit, hukumnya harus dijalankan dan ditegakkan. Kemaslahatan tersebut bisa dilihat dari beberapa aspek, diantaranya Pencipta atau penemu temuan baru tersebut telah membelanjakan begitu besar waktu, biaya dan fikirannya untuk menemukan suatu temuan baru, maka sudah selayaknya dilindungi temuannya tersebut.

a. Mayoritas ulama dari kalangan mazhab Maliki, Syafi'I dan Hambali berpendapat bahwa hak cipta atas ciptaan yang orsinil dan manfaat tergolong harta berharga sebagaimana benda jika boleh dimanfaatkan secara syara` (hukum Islam). ${ }^{19}$

b. Wahbah al-Zuhaili menegaskan bahwa hak cipta adalah hak yang dilindungi oleh syara` atas dasar qaidah istishlah tersebut, mencetak ulang tanpa seizing yang sah dipandang sebagai pelanggaran atau kejahatan terhadap hak cipta; dalam arti bahwa perbuatan tersebut adalah kemaksiatan yang menimbulkan dosa dalam pandangan Syara` dan merupakan pencurian yang mengharuskan ganti rugi terhadap pemegang hak cipta atas ciptaan yang dicetak secara melanggar dan zalim, serta menimbulkan kerugian moril yang menimpanya. Dalam Hukum Islam, Hak cipta dipandang sebagai salah satu huquq maliyyah (hak kekayaan) yang mendapat perlindungan hukum (mashu) sebagaimana mal (kekayaan). ${ }^{20}$

c. Keputusan Fatwa Majelis Ulama Indonesia Nomor : 1/MUNAS VII/MUI/15/2005 Tentang Perlindungan Hak Kekayaan Intelektual (HKI) bahwa Hak cipta yang

${ }^{19}$ Fathi al-Duraini, Haqq al-Ibtikar fi al-Fiqh al-Islami al-Muqaran, (Bairut: Mu`assasah al-Risalah, 1984), hal. 20

${ }^{20}$ Wahbah al-Zuhaili, al-Fiqh al-Islami...., juz 4, hal. 2862 
mendapat perlindungan hukum Islam adalah Hak Cipta yang tidak bertentangan dengan hukum Islam. Hak cipta dapat dijadikan obyek akad (al-ma'qud'alaih), baik akad mu'awadhah (pertukaran, komersial), maupun akad tabarru'at (nonkomersial), serta dapat diwaqafkan dan diwariskan. Setiap bentuk pelanggaran terhadap Hak Cipta, termasuk namun tidak terbatas pada menggunakan, mengungkapkan, membuat, memakai, menjual, mengimpor, mengekspor, mengedarkan, menyerahkan, menyediakan, mengumumkan, memperbanyak, menjiplak, memalsu, membajak Hak Cipta milik orang lain secara tanpa hak merupakan kezaliman dan hukumnya adalah haram.

\section{Analisis kegiatan ekonomi atas hak cipta dalam ekonomi Islam}

Hak Cipta adalah hak untuk menikmati secara ekonomis hasil dari suatu kreativitas intelektual dari yang bersangkutan sehingga memberikan hak privat baginya untuk mendaftarkan, dan memperoleh perlindungan atas karya intelektualnya. Sebagai bentuk penghargaan atas karya kreativitas intelektualnya tersebut Negara memberikan Hak Eksklusif kepada pendaftarannya dan/atau pemiliknya sebagai Pemegang Hak mempunyai hak untuk melarang orang lain yang tanpa persetujuannya atau tanpa hak, memperdagangkan atau memakai hak tersebut dalam segala bentuk dan cara. Tujuan pengakuan hak ini oleh Negara adalah setiap orang terpacu untuk menghasilkan kreativitas-kreavitasnya guna kepentingan masyarakat secara luas. ${ }^{21}$

Kalangan ulama kontemporer bersepakat bahwa hak-hak cipta itu menurut syariat terpelihara. Para pemiliknya bebas memperlakukan hak cipta itu sekehendak mereka. Tak seorang pun yang berhak melanggarnya, namun dengan syarat, jangan sampai dalam karya-karya tulis yang melanggar syariat Islam yang lurus. Itulah yang menjadi keputusan akhir dari Lembaga Pengkajian Fiqih Islam yang lahir dari Organisasi Muktamar Islam pada pertemuan kelima di Kuwait tahun 1409 H, bertepatan dengan tahun $1988 \mathrm{M}$.

Pertama, dalil mencari kemaslahatan. Pendapat yang menyatakan bahwa hak cipta penulisan itu bernilai dan layak dipasarkan dapat melanggengkan kemaslahatan 2004), hal. 5

21 Ahmad Fauzan, Perlindungan Hukum Hak Kekayaan Intelektual, (Bandung, CV Yama Widya, 
umum. Dalam artian, diharapkan keberlanjutan pengkajian ilmiah dan mendorong para ulama dan ahli ijtihad untuk melanjutkan penelitian mereka, sementara hak cipta mereka tetap terpelihara dari orang yang tidak bertanggung jawab. Syariat Islam diturunkan untuk merealisasikan kemaslahatan dan menghindari kerusakan. Dimana ada kemaslahatan, di situ ada ajaran Islam.

Kedua, dalil kebiasaan. Terjadinya persoalan ini dan kesepakatan kaum muslimin melakukannya, merupakan dalil bahwa mereka sudah mengetahui dibolehkannya urusan itu. Jelas bahwa kebiasaan itu memiliki pengaruh pada hukum syariat. Itu merupakan hak yang permanent, bukan sekedar hak semata. Berarti hak itupun bisa berpindah dan bisa dijualbelikan, bila dirusak atau dihilangkan, harus dipertanggungjawabkan dan diberi ganti rugi.

Ketiga, pendapat yang dinukil dari sebagian ahli hadits yang membolehkan mengambil upah dalam menyampaikan atau mengajarkan hadits. Para ulama ahli hadits biasanya membolehkan siapa saja yang mereka kehendaki untuk meriwayatkan haditshadits mereka, dan melarang sebagian lain yang tidak mereka kehendaki, bila orangorang tersebut dianggap tidak memiliki kompetensi dibidang periwayatan. Dari sebagian ulama ahli hadits juga diriwayatkan dibolehkannya mengambil upah dalam mengajarkan hadits, diqiyaskan dengan dibolehkannya mengambil upah dalam mengajarkan al-Qur'an.

Keempat, qiyas seorang produsen atau pembuat barang bisa menikmati hasil karyanya, memiliki kebebasan dan kesempatan untuk orang lain memanfaatkannya atau melarangnya.

Kelima, kaidah Saddudz Dzara-i' (menutup jalan menuju haram). Karena pendapat yang menyatakan dibolehkannya menjual hak cipta mengandung upaya memberikan dorongan bagi para pemikir dan ulama untuk semakin produktif dan semakin giat melakukan penelitian ilmiah. Menggugurkan nilai jual dari karya cipta itu sendiri bisa menyebabkan mereka meninggalkan pekerjaan tersebut dan beralih ke pekerjaan lain untuk menjadi sumber penghidupan mereka. Hal ini tentu saja menyebabkan umat kehilangan kesempatan mendapatkan hasil dari karya mereka, 
bahkan menyebabkan matinya gairah untuk mencipta pada banyak kalangan peniliti ilmiah. Jelas yang timbul adalah kerusakan yang besar.

Keenam, dasar ditetapkannya nilai jual adalah adanya mutu yang dibolehkan syariat. Mutu dari karya ilmiah bagi umat masa kini dan masa mendatang amat jelas sekali. Kalau para ulama telah mengakui nilai jual dari berbagai fasilitas yang lahir dari sebagian jenis hewan, seperti ulat misalnya, atau kicauan burung, suara beo misalnya, manfaat atau fasilitas yang berasal dari karya ilmiah tentu lebih layak dan memiliki nilai jual. Manfaat yang seharusnya dinikmati oleh pemiliknya. Manfaat itu lebih layak diperhatikan, karena lebih besar hasilnya dan lebih banyak faedahnya.

\section{KESIMPULAN}

Usaha yang sungguh-sungguh dari seorang pencipta dalam hal upaya menciptakan suatu karya melalui suatu pengorbanan baik waktu, pikiran dan lain sebagainya, memerlukan suatu perlindungan untuk menghormati jerih payahnya tersebut. Dengan adanya ketentuan syariah dan perlindungan Undang-undang tentang hak cipta memberikan perlindungan hukum yang memadai, tentunya supaya kemampuan hak intelektual, kreativitas, atau keahlian masyarakat dapat tumbuh sejalan dengan iklim persaingan usaha yang sehat. Hak cipta dapat dibenarkan oleh Ekonomi Islam dari segi keadilan distributif. Pertimbangan mengenai keadilan merupakan alasan yang kuat untuk mendukung hak cipta. Adil bahwa penemu mendapatkan reward karena memberikan layanan bagi masyarakat. Sebaliknya, akan menjadi tidak adil jika orang lain menjadi "penumpang gelap" atas biaya orang lain yang telah berusaha melakukan penelitian dan penemuan baru. Insentif juga perlu diberikan kepada penemu karena tanpa dia tidak mungkin terjadi perkembangan seni, ilmu dan teknologi. Karena kebebasan yang dimiliki seorang penemu merupakan modal yang yang tak ternilai bagi kemajuan masyarakat. Oleh karena itu, perlindungan atas apa yang ia temukan pantas diberikan oleh masyarakat. 


\section{DAFTAR PUSTAKA}

al-Duraini, Fathi. Haqq al-Ibtikar fi al-Fiqh al-Islami al-Muqaran, Bairut: Mu’assasah alRisalah, 1984

al-Zuhaili, Wahbah. al-Fiqh al-Islami wa Adilllatuhu, juz 4, Bairut: Dar al-Fikr al-Mu`ashir, 1998

Badrulzaman, Mariam Darus. Mencari Sistem Hukum Benda Nasional, Bandung: BPHNAlumni, 1983

Damian, Eddy. Hukum Hak Cipta, Bandung: Penerbit Alumni, 2002

Dewantara, Ki Hajar. Kebudayaan, (Jogjakarta: Majelis Luhur Persatuan Taman Siswa, 1967

Fauzan, Ahmad. Perlindungan Hukum Hak Kekayaan Intelektual, Bandung, CV Yama Widya, 2004

Muhammad, Abdul Kadir. Kajian Hukum Ekonomi Hak Kekayaan Intelektual, Bandung: PT. Citra Bakti, 2001

Pusat Pembinaan dan Pengembangan Bahasa, Kamus Besar Bahasa Indonesia, Jakarta: Balai Pustaka, 1996

Pusat Pengkajian dan Pengembangan Ekonomi Islam (P3EI), Ekonomi Islam, Jakarta: PT. Raja Grafindo Persada, 2008

R. Tjitrosudibio, dan R. Subekti Kitab Undang-undang Hukum Perdata, Jakarta: Pradnya Paramita, 1982

Simatupang, Richard Burton. Aspek Hukum dalam Bisnis, Jakarta: PT. Rineka Cipta, 2003

Sofwan, Sri Soedawi dan Masjchoen. Hukum Perdata: Hukum Benda, Yogyakarta: Liberty, 1981

Subekti, Pokok-Pokok Perdata, Jakarta: PT. Intermasa, 1980

Tunggal, Hadi Setia. Undang-Undang Hak Cipta (UU No. 19 Tahun 2002), Jakarta: Harvindo, 2003

Undang-Undang Hak Cipta No. 19 Tahun 2002 